\title{
Automation of geospatial objects converting into the classifiers according to the European data standards
}

\author{
Zarytskyi O. V., Kostenko O. B., Bulaienko M. V. \\ O. M. Beketov National University of Urban Economy in Kharkiv, \\ Department of Computer Science and Information Technology, Faculty of Management, \\ 17 Marshal Bazhanov Str., 61002, Kharkiv, Ukraine
}

(Received 21 April 2020; Revised 12 May 2020; Accepted 31 May 2020)

\begin{abstract}
In the paper, the concept of the formation of the national spatial data infrastructure (NSDI) in Ukraine has been investigated, the complex NSDI industry standards and the classes of objects of the urban-planning cadaster have been analyzed. The complex of problems influencing the development of geo-informational resources in Ukraine has been determined. Given the current state of the national infrastructure of geospatial data and the urgency of the problems of the use of archival geospatial databases (GDB), a need to develop algorithms for the creation of a unified basis for geographic information systems has been shown. The method of automation of the conversion of differentiated GDBs according to the updated rules for the digital description of all geospatial objects instances is proposed. The sets of digital maps are considered as three-dimensional arrays of data. This approach allows us to better navigate in algorithmic processes taking into account a lot of rules for the conversion of objects between two classifiers of different structures.
\end{abstract}

Keywords: geospatial data infrastructure, object classes, urban-planning cadastre, GDB, classifier, database conversion.

2010 MSC: $68 \mathrm{P} 15$

DOI: $10.23939 / \mathrm{mmc} 2020.02 .228$

\section{Introduction}

Geoinformation in modern conditions has become an important strategic resource of management, a significant factor in the sustainable social and economic development of the country and its integration into the global information space. A significant amount of geospatial data has been accumulated in the departmental institutions of geoinformational resources of Ukraine for the last twenty years. The processes of accumulation and presentation of such information were mostly carried out without common technical regulations and methodological principles. Requirements for the structure, composition and quality of geospatial data were not coordinated. Data was recorded using a variety of classification systems and software and technological tools.

Uncoordinated activities have led to inconsistencies in information flows. Thus, in state bodies or local self-government bodies, information is sufficiently differentiated in format of presentation (for example, information on real estate, engineering communications and facilities, address registers, names, etc.). Consequently, the existing state of geographic information resources is characterized by the following set of problems:

- predominantly departmental principle of geoinformation resources formation;

- significant duplication of topographic and geodetic and cartographic works;

- lack of a unified system of national standards for geoinformation products;

- lack of available metadata for geodetic and cartographic works and geospatial data created by their results;

- lack of organizational structure and network of geographic information centers responsible for the creation and maintenance of geospatial data bases at the national, regional and local levels [5]. 
The analysis of these problems suggests the need to improve the state policy in the sphere of the formation and use of geoinformation resources and the development of geospatial data infrastructure. In Ukraine for a long time the basis for the implementation of the geospatial database (GDB) of large scale (topographic plans) has been the following documents:

- Basic provisions for the creation of topographic plans of scale 1:5000, 1:2000, 1:1000 and 1:500, the Main Directorate of Geodesy, Cartography and Cadastre under the Cabinet of Ministers in Ukraine Decree No. 3 of January 24, 1994;

- Symbols for topographical plans of scale 1:5000, 1:2000, 1:1000, 1:500, the Ministry of Natural Resources in Ukraine Decree No. 295 dated August 3, 2001.

The similar package of documents provides the creation of GDB of smaller scale (topographic maps). There are also approved lists of conditional abbreviations that are used in topographical materials. Since 2000, the European Technical Committee for Geographic Information and Geomatics ISO / TC $211[11,21]$ has published a series of international standards ISO 19100 Geographic Information / Geomatics. From 2009 to 2017, 16 standards were implemented from the ISO 19100 complex that defines geographic data models, administration of these data and geoinformation services. In 2015, the decree of the Ministry of Region [20] approved the codes and names of the classes of objects of the city-planning cadastre. In 2018, the Cabinet of Ministers in Ukraine approved a bill that should establish the legal framework for the creation, operation and development of the National Spatial Data Infrastructure (NSDI) [5, 24]. The standard DSTU 8774: 2018 "Geographic information: rules for modeling geospatial data" was developed.

It was adopted the set of industry standards (Standards for Organization in Ukraine (SOU)) [1], which provides information and functional compatibility of topographic data based on the unified structure of the topographic data base (hereinafter TDB), a unified classification and coding system for topographic objects and their attributes, rules of digital description of vector data and digital models of relief, metadata for topographical objects and sets of topographical data, formats of export / import of topographic data in processes of information interaction of computer contents and TDB systems with other systems.

Basic geospatial data is the set of publicly available standardized geospatial data as a unified basis for integration and sharing in geographic information systems [1]. The basic set of geospatial data forms the core of geoinformation resources of infrastructure which spatially and thematically combines all geospatial and operational data that are jointly produced and used in the integrated geographic information environment. Basic geospatial data is formed at the national, regional and local levels. Consequently, at the present time the basis for an agreed technological policy, for common methodological foundations and technical regulations for the creation of geoinformation systems under the new structure has been created.

\section{Analysis of recent researches and publications}

Many scientists have devoted the research to the issues of the strategy in forming NSDI and the application of the conceptual framework for the assessment and quality assurance of geospatial data.

Sanderson M., et al. [22] researches the possibility of making seamless queries to remote databases in the global INSPIRE data model by users. The paper considers the problems of semantic compatibility and data quality. It is proposed to encapsulate thematic data in rule sets, which will be check specific data instances for compliance. Rule-based processing is essentially seen as a new phenomenon in the geospatial world. This approach also allows knowledge to be managed through unified rule storage, with everyone gaining access to the same rules described in the same way for all organizations. Validation of logical consistency determines the directions of further development of NSDI concept.

Karpinsky Yu. O., Lyaschenko A. A., et al. [13-16] explore new systems of standardization and technical regulation in Ukraine, which are harmonized with the documents of international organizations for standardization in the field of geographical information / geomatics. A set of standards 
"Topographical Database" has been developed, which is based on the methodological principles of compiling a series of international standards ISO 19100 and takes into account the features of digital modeling of topographic objects in object-relational databases of geospatial data. A reference model of a topographical database is proposed, which reflects the general approaches to the standardization of digital modeling of topographical objects. It is established that the methodology of quality management of geospatial data and geoinformation services is still in the process of formation, awareness of problems and finding ways to solve them.

Zaiets I. M., et al. [25] considers NSDI as a tool to increase the efficiency of production and use of geospatial data and geographic information systems in the interests of a whole society. It is substantiated that the achievement of information and functional compatibility of different sets of geospatial data, harmonization of rules and procedures for the production of geoinformation resources form a new policy in the geoinformation environment. It is given significant differences between traditional cartographic production and NSDI, among which the formation of geospatial databases, multiple and multidisciplinary use in GIS, the preparation of new types of spatial information.

Sossa R. I., et al. [23] examines the state of topographic and geodetic support of the national security and defense sector. It is established that the way to solve the problem of creating a single system of qualitative data lies through the international experience of creating NSDI. It is emphasized that without high-quality and up-to-date spatial data it is impossible to guarantee an adequate and flexible response to the whole spectrum of threats to the national security of Ukraine, to rationally use the opportunities and resources available to the state.

Boroviy V.O., et al. [2] provides the theoretical studies of the ranking of information systems on a subset of normative documents. It is spoken in detail the problem of duplication of information and optimization of connections between segments of the branch of economic activity. The necessity of ranking of information systems of branches of economic activity for formation of unambiguous and qualitative geospatial data is noted.

Kay S. E. [12] emphasizes that the collection and maintenance of geospatial data should be based on the principle of "collect once - use many times". However, the example of the South African Spatial Data Infrastructure (SASDI) shows a number of problems during the exchange of geospatial data. The cases of missed information and duplication of geospatial data sets are detected by users. It is being noted the need for supporting data quality, getting knowledge and finding better methods for data storage.

Dyshlyk O. P., et al. [6] provides a number of principles that should be followed for creating NSDI. Principle 1: Design, not improvement - the optimal project is based on planning, evaluating and making decisions that involve new innovative approaches. Principle 2: classification, not generalization that is one of the ways to integrate several matched systems into a larger one, is to create a structured system. Principle 3: Open Solutions - there are many arguments in favor of the principle of using open solutions. But some issues of practical application remain undiscovered and are still in the field of scientific research.

\section{Current issues}

Basing on these changes in 2018 the work of the departments at all levels has become noticeably intensified in order to implement the concept of NSDI and to unify the generally accepted structure of the geospatial data base $[1,5,6,8,24,25]$.

At the same time the vast amount of archival information accumulated for many years by the state, local departments, institutions and project organizations remains rather valuable and in demand. The quantitative and qualitative differentiation of such a GDB adds considerable complications in the transition to new standards of work.

The purpose of the paper is to analyze the archival bases of geospatial data in Ukraine, as well as to develop ways of integrating archival bases of geospatial data into a unified format of geographic information system. 


\section{Comparison of old and standardized rules for the digital description of geospatial objects}

It should be noted that the average enterprise in the field of land relations for 6 years of its activity only on the geospatial of Kharkiv has formed a database of topographical data with a total of more than 700 thousand spatial objects with its semantics and uniqueness. The whole set of data was formed on the old requirements and in the early stages of the formation of the database some amount of information was not created comprehensively or ignored at all.

It should be considered in more detail the group of the gas transmission network objects. To compare data models, one and the same object can be represented in three classification systems (see Tabl. 1).

Table 1. Comparison of pipeline identification data in old and standardized rules of digital description of vector data.

\begin{tabular}{|c|c|c|c|}
\hline \multirow[b]{2}{*}{$\begin{array}{l}\text { The name of the } \\
\text { feature }\end{array}$} & \multicolumn{3}{|c|}{ The value of a class instance: } \\
\hline & $\begin{array}{l}\text { old description (used } \\
\text { by a number of } \\
\text { design organizations) }\end{array}$ & $\begin{array}{l}\text { new description } \\
\text { (according to } \\
\text { standards) }\end{array}$ & $\begin{array}{l}\text { new description } \\
\text { (proposed by the } \\
\text { local department } \\
\text { according to the } \\
\text { standard) }\end{array}$ \\
\hline TYPE & $\begin{array}{l}\text { Gas pipeline of } \\
\text { medium pressure }\end{array}$ & Pipelines & Gas pipeline \\
\hline ID & $\begin{array}{l}\text { Gas pipeline of } \\
\text { medium pressure }\end{array}$ & TD_TrubProv & GAS_PIPELINE \\
\hline CODE & 51314200 & 51310000 & $\begin{array}{l}\text { As domain: } \\
51314100 \\
51314200 \\
51314300\end{array}$ \\
\hline $\begin{array}{c}\text { Link to list of directory } \\
\text { object types }\end{array}$ & not provided & $08 \_1$ & 4.4 .2 \\
\hline
\end{tabular}

Following to the three options for organizing data from Tabl. 1 it is compared classifiers by the number of spatial classes:

- according to the old rules of implementing the classifier, the workset for the creation of a topographic scale of 1:500 $C^{O L D}$ is represented by 502 spatial classes $-C^{O L D}=[1,502]$;

- according to the new rules for implementing the classifier [17] the workset according to the standards for the creation of a topographic database of all scales $C^{N 1}$ is represented by 110 space classes $C^{N 1}=[1,110]$

- according to the new rules for the implementation of the classifier, the workset following to the recommendations of the local department of urban planning and architecture [4] for the creation of a topographic scale of 1:500 $C^{N 2}$ is represented by 53 space classes $-C^{N 2}=[1,53]$.

Thus by the number of classes the concept of a new classification of geospatial data is significantly unified. According to the semantic context the information about the object is provided without any significant differences unlike naming, typing, and encoding of the same spatial object's data in two (and more) classification structures.

According to standards [1] there are no restrictions or rules for displaying a generalized abstract type Geometrya for representing geometric data of the database management system (DBMS) in which environment the GDB is implemented. If you try to submit the same structure of vector data in the UML diagrams of the old and new classifications (see Fig. 1 and Fig. 2) the direct transfer of the attribute array without loss or distortion of data is impossible. 


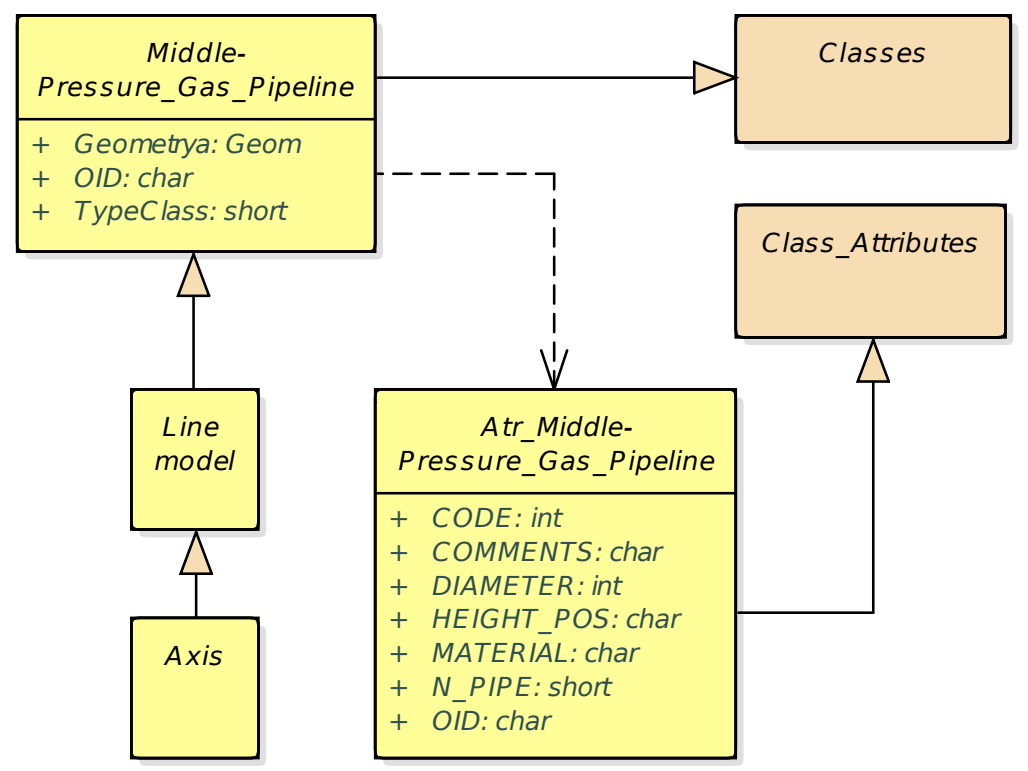

Fig. 1. UML diagram for representing the spatial properties and attributes of the medium pressure gas pipeline according to the old rules of the vector data digital description.
It should be noted that even with the same graphic representation of objects the database attribute information differs significantly. The use of the archive is impossible in the new geospatial data infrastructure without proper reorganization of information. In the past the developer of the set of works objects was forced to reorganize the same instances of classes but according to new standards.

One instance transforming may take up to 30 minutes, depending on the level of the specialist's knowledge and the software specifics, the complexity of the spatial object and its geometric localization description. What have to be done if to the "mark of heights" class on the territory of 6 hectares includes more than 800 instances of point objects - pickets and all the spatial classes on the same territory involved 134? The total power of such a work card can reach over 5000 copies. Work with attributive data in the GDB on an average of about 700 thousand objects is not a commensurate and unjustified cost for each enterprise. Therefore, the implementation of an automized transition to new standards is relevant. It is necessary to automate the process of conversion of differentiated GDBs to updated rules for the digital description of all instances of geospatial objects.

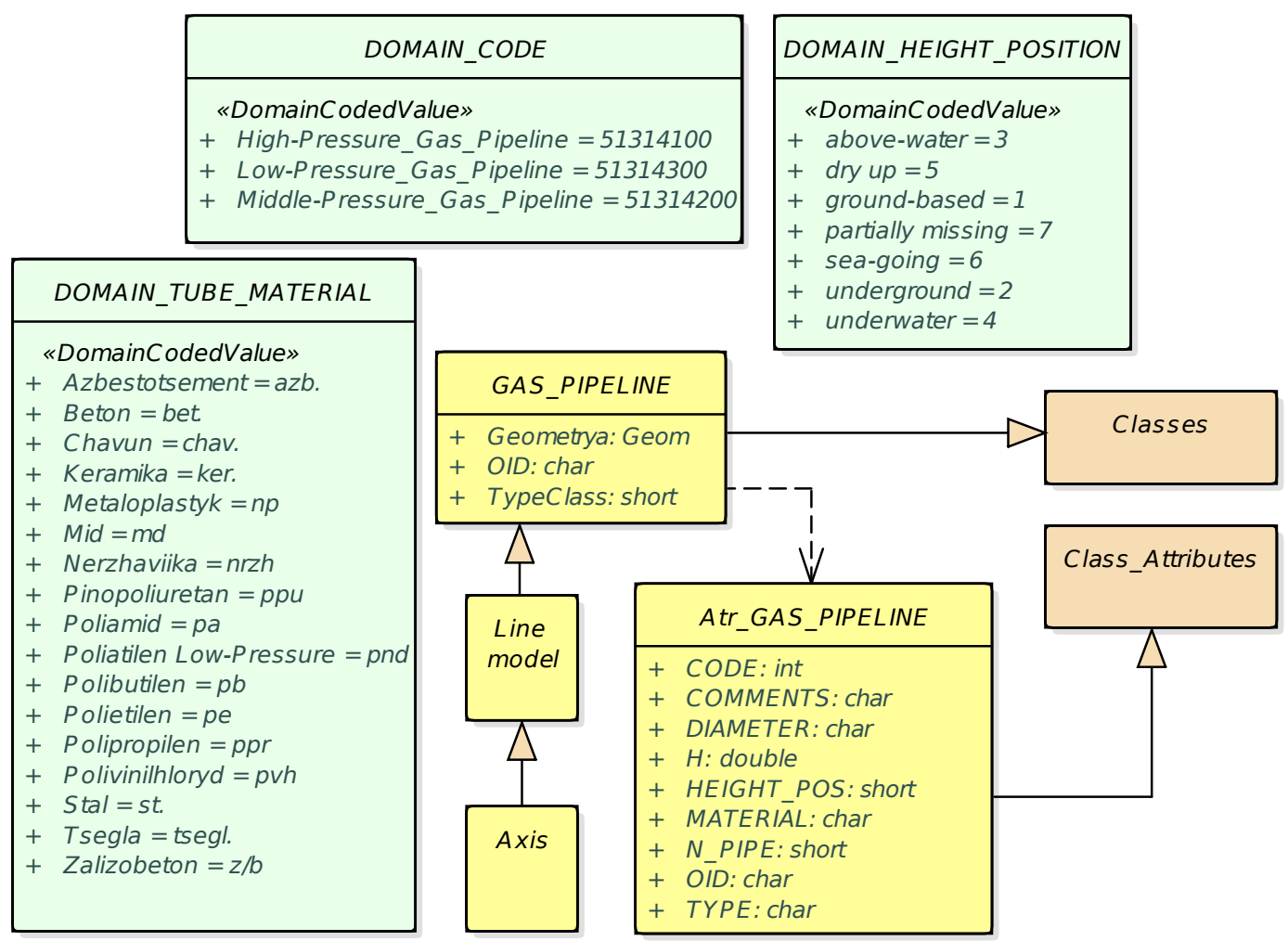

Fig. 2. UML diagram for representing the spatial properties and attributes of the gas pipeline according to the updated rules of the vector data digital description. 


\section{Mathematical model of maps' worksets with different classifiers}

The digital model of the terrain classifier proposed by the authors is the basis of spatial information which will allow switching to the component of UkrNSDI that is the basic sets of geospatial data in the standardized digital representation form. The classifier is developed for a specific application and should foresee all possible types of objects combinations and their characteristics. Information is presented in digital form as a set of description of vector map layers, types of objects and their symbols as well as types of semantic (attributive) characteristics and values that serve as the core of the geodatabase of the digital model.

Thus, the digital classifier consists of the following elements:

- layers (spatial classes, tables) containing objects;

- parameters (fields, attributes) in which the characteristics of objects are stored;

- libraries of symbols which defines the mapping of layers and parameters.

Conceptually, the conversion process should take place in the following sequence:

- open working data set based on $C^{O L D}=[1,502]$;

- launch the conversion process using the tool developed:

o call the advanced user interface tool;

o extract all attributive information about the objects sequentially to the clipboard;

o open a new card template based on the new classifier, for example $C^{N 2}=[1,53]$;

o sequentially for each object in the old classification the script code automatically defines a new list of code description data and connects the appropriate rules for transition between old and new attributes using the clipboard;

- get working map with data set based on $C^{N 2}=[1,53]$.

Worksets of cards are identified with classifiers as a set of plural classes which are templates for preserving geospatial specimens. A set is a structure that is a dataset of the same type that does not repeat (each element of the set is unique). A set can be regarded as a set of classes that form a superclass classifier as a whole. The order of following elements of a set is not of fundamental importance.

Based on the analysis of normative documents, a complete set of conversion rules (more than 5 thousand lines of code describe 479 rules) of operational and spatial data was developed and algorithmic implemented:

$$
\Omega^{1} \stackrel{F}{\rightarrow} \Omega^{2}
$$

where $\Omega^{1}=\{X, N, P\}$ and $\Omega^{2}=\{Y, M, Q\}$ represent worksets in the old and new classifiers respectively,
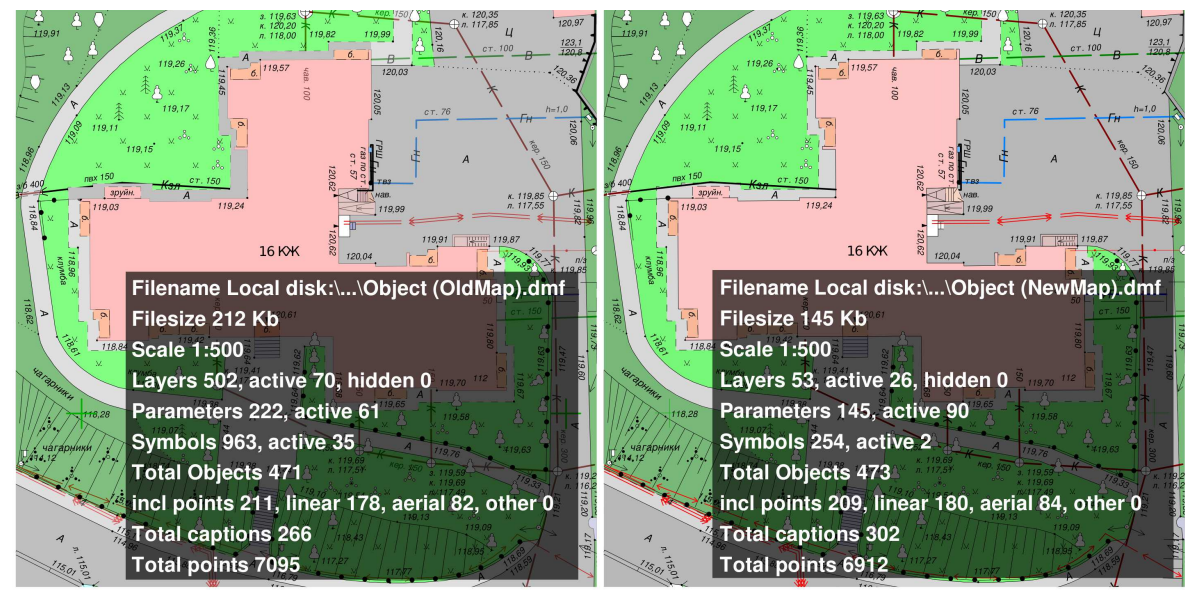

Fig. 3. Illustration of statistics of worksets and fragments of vector data in set $\Omega^{1}$ (left) and $\Omega^{2}$ (right).

which consists of a plurality of classes (layers), plural instances (objects) and multiple attributes; $\mathrm{F}$ is the set of functional rules described below. Because of the need to create conversion rules, the final number of classes and attributes will always be known. On the base real data it is presented the experimental sample (see Fig. 3). 
A plurality of classes (layers):

$$
X=\left\{x_{1}, x_{2}, \ldots, x_{i}, \ldots, x_{I}\right\}, \quad Y=\left\{y_{1}, y_{2}, \ldots, y_{j}, \ldots, y_{J}\right\},
$$

where $x_{i}$ and $y_{j}$ are the elements of sets $X$ and $Y$ appropriately; $i=1, I, j=1, J ; I$ is the number of classes in old classifier (502), $J$ is the number of classes in new classifier (53).

A plurality of instances (objects):

$$
N=\left\{n_{1}, n_{2}, \ldots, n_{k}, \ldots, n_{K}\right\}, \quad M=\left\{m_{1}, m_{2}, \ldots, m_{l}, \ldots, m_{L}\right\}
$$

where $n_{k}$ and $m_{l}$ are the elements of sets $N$ and $M$ appropriately; $k=1, K, l=1, L ; K$ is the number of instances (objects) in workset $\Omega^{1}, L$ is the number of instances (objects) in workset $\Omega^{2}$.

A plurality of multiple attributes:

$$
P=\left\{p_{1}, p_{2}, \ldots, p_{r}, \ldots, p_{R}\right\}, \quad Q=\left\{q_{1}, q_{2}, \ldots, q_{g}, \ldots, q_{G}\right\},
$$

where $p_{r}$ and $q_{g}$ are the elements of sets $P$ and $Q$ appropriately; $r=1, R, g=1, G ; R$ is the number of attributes in old classifier (76), $G$ is the number of attributes in new classifier (127).

It is obviously that worksets of cards $\left(\Omega^{1}, \Omega^{2}\right)$ are three-dimensional arrays and they are represented by classes $(X, Y)$, rows are instances $(N, M)$ and columns are attributes $(P, Q)$ (see Fig. 4). This allows a single element of a three-dimensional array to be mathematically described as follows:

- In the workset $\Omega^{1}$ element $p_{i, k, r}$ is an instance $n_{i, k}$ of the class $x_{i}$;

- In the workset $\Omega^{2}$ element $q_{j, l, g}$ is an instance $m_{j, l}$ of the class $y_{j}$.

There is the task of converting instances between classifiers (see Fig. 4 and Fig. 5). When converting a digital card to an updated classifier it should be noted some features:

- if $n_{k} \notin x_{i}\left(m_{l} \notin y_{j}\right)$, then $n_{i, k}=$ "null" ( $m_{j, l}=$ "null");

- if $p_{r} \notin n_{i, k}\left(q_{g} \notin m_{j, l}\right)$, then $p_{i, k, r}=$ "null" $\left(q_{j, l, g}=\right.$ "null");

- $J \leqslant I, L=K, G \geqslant R$.

Each class has its own combination of attributes but their total number in the classifier is static. Provided that each class consists of all possible attributes of the classifier, non-essential and unrelated attributes is left empty (analogy with "null").

If a separate card class $x_{i}$ is described with its instances, then all classes of maps can be represented with their instances for formula:

$$
\begin{gathered}
\left\{n_{1,1}, n_{1,2}, \ldots, n_{1, k}, \ldots, n_{1, K}\right\} \\
\left\{n_{2,1}, n_{2,2}, \ldots, n_{2, k}, \ldots, n_{2, K}\right\} \\
\ldots \\
\left\{n_{i, 1}, n_{i, 2}, \ldots, n_{i, k}, \ldots, n_{i, K}\right\} \\
\ldots \\
\left\{n_{I, 1}, n_{I, 2}, \ldots, n_{I, k}, \ldots, n_{I, K}\right\}
\end{gathered}
$$

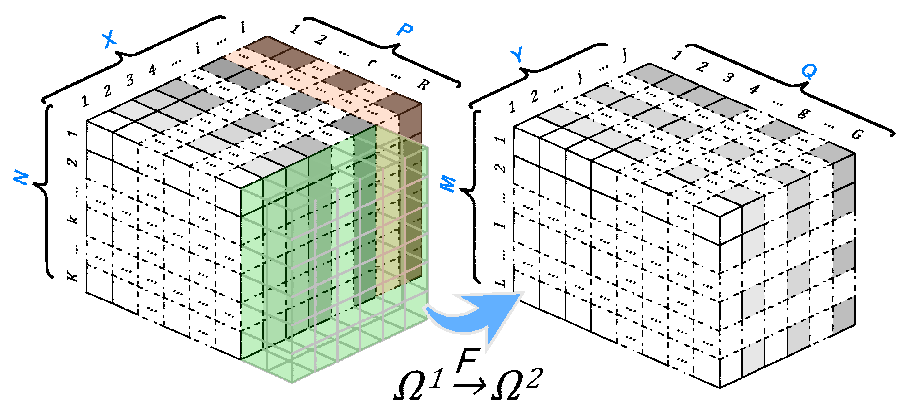

Fig. 4. Conceptual model for converting worksets of digital maps to updated classifiers.

If a separate card class $n_{i, k}$ is described with its attributes, then a particular class $x_{i}$ can be represented with the set of companion instance attributes:

$$
\begin{gathered}
\left\{p_{i, 1,1}, p_{i, 1,2}, \ldots, p_{i, 1, r}, \ldots, p_{i, 1, R}\right\} \\
\left\{p_{i, 2,1}, p_{i, 2,2}, \ldots, p_{i, 2, r}, \ldots, p_{i, 2, R}\right\} \\
\ldots \\
\left\{p_{i, k, 1}, p_{i, k, 2}, \ldots, p_{i, k, r}, \ldots, p_{i, k, R}\right\} \\
\ldots \\
\left\{p_{i, K, 1}, p_{i, K, 2}, \ldots, p_{i, K, r}, \ldots, p_{i, K, R}\right\}
\end{gathered}
$$


During converting and transformation of a digital description of vector data, it must definitely go through a series of rules. This makes it possible to represent complex spatial structures (objects, layers) through their attributes as a set of functional rules $(F)$. The rules are a function of a single attribute in a new workset from one or more attributes of the old data set dependence:

$$
q_{j, l, g}=f_{j, l, g}\left\{p_{i, k, 1}, p_{i, k, 2}, \ldots, p_{i, k, r}, \ldots, p_{i, k, R}\right\},
$$

or unifying the description of variables to general type we obtain formula:

$$
q_{j, l, g}=f_{j, l, g}\{X, N, P\} .
$$

Expressions with the presented functions (8) in all components of the workset $\Omega^{2}$ will form the core of the transformation process (see Fig. 4 and Fig. 5).

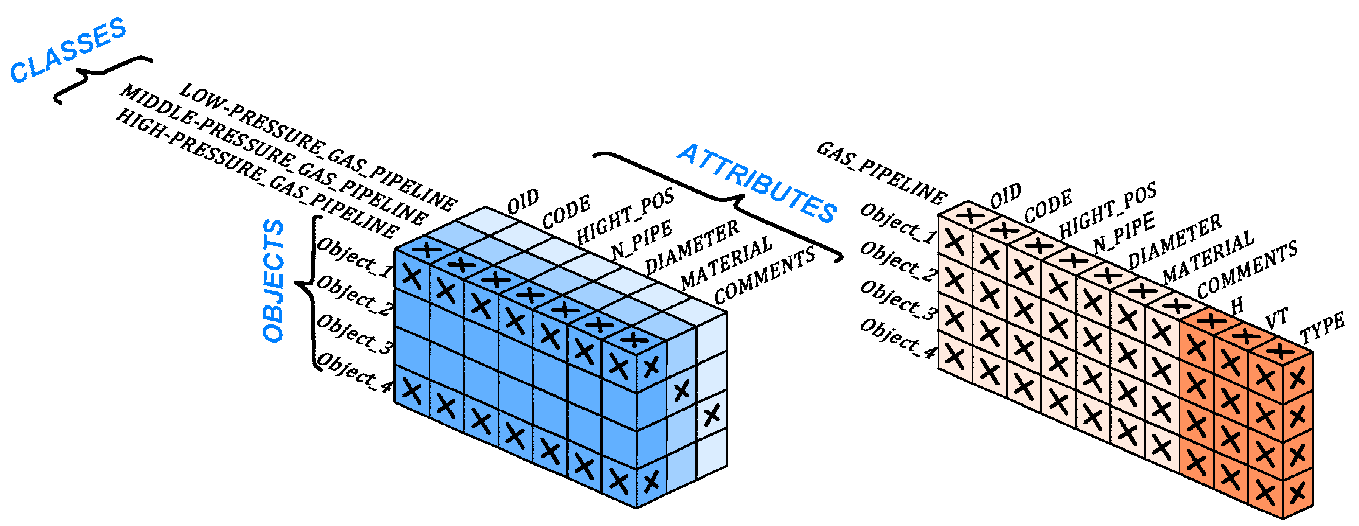

Fig. 5. Data converting by the example of gas pipeline class.

\section{Control-flow chart for converting sets of geospatial data}

The control-flow chart oriented to support the script-code base in the software of any cartographic editor is depicted on Fig. 6.

In the implemented chart we can distinguish 3 main stages:

I. In the part of the attribute feature the clipboard is formed which will store a list of instances of the archive database $\Omega^{1}$.

II. In the part of the geometric component the transfer of the archival database instance $\Omega^{1}$ to a standardized database $\Omega^{2}$ is carried out.

III. Converting the archival database from old spatial data classes into new one instance in a workset environment $\Omega^{2}$ is carried.

The environment of Digitals development $[9,10]$ was chosen for the program realization of converting database objects. Geodetic enterprises create maps in the format Digitals DMF in Ukraine. This makes it easy to exchange digital cards without losing their content and design. The program also opens and writes maps in popular formats Autocad DXF / DWG, ArcGIS Shape, MapInfo MID / MIF, Microstation DGN, XML and others.

Digitals is a well-developed cartographic editor to have automation tools for routine tasks. One of these tools is scripting language which has been integrated in the program Digitals Script. Digitals Script is the internal program environment in a simplified programming language which allows to create procedures for the execution of certain tasks and operations using software code. In total Digitals scripts now have more than 400 different functions [10]. Their list is expanding, some of them were involved in converting geospatial data into a workset with an updated classifier. 


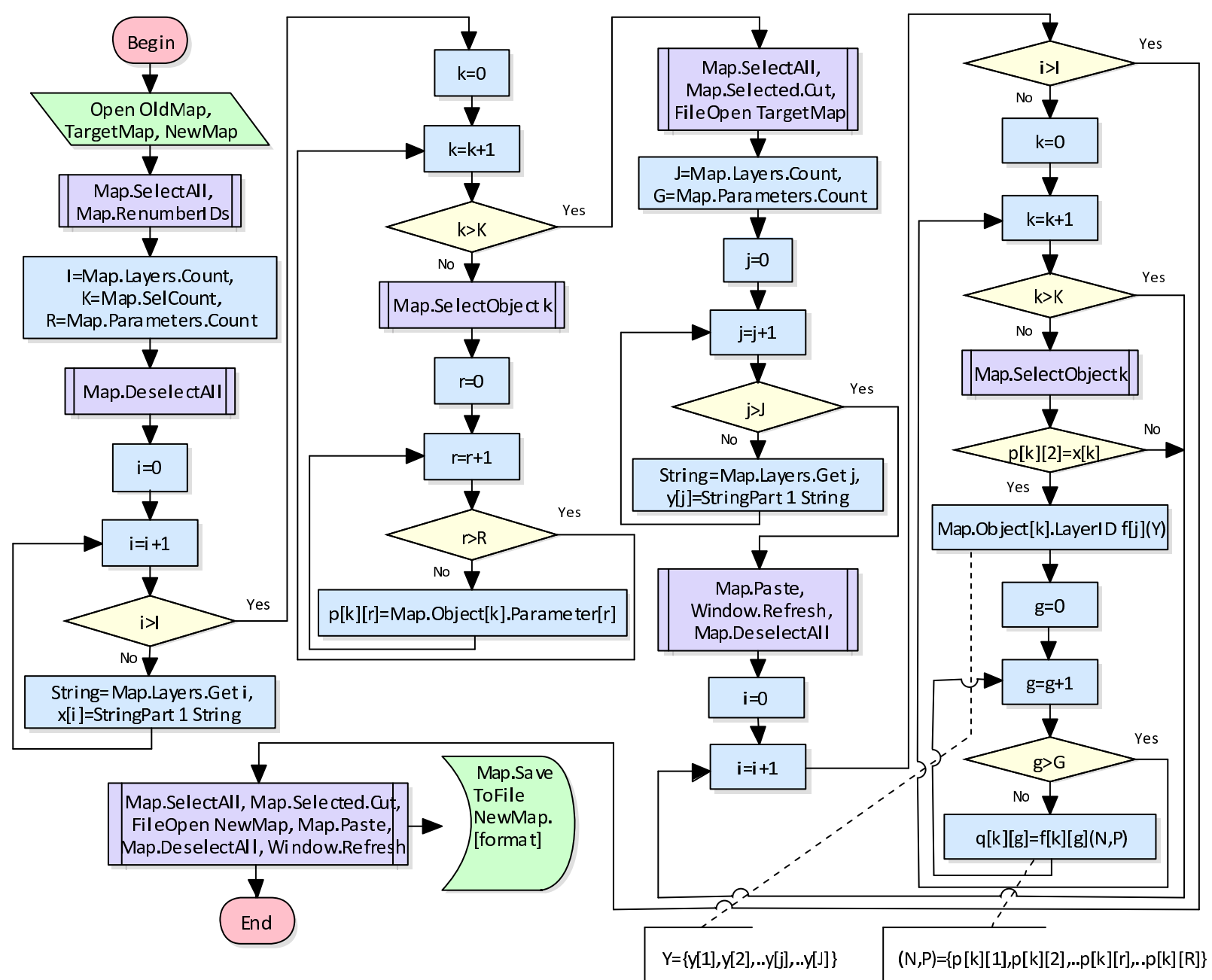

Fig. 6. Flow Chart is algorithm for converting instances between worksets of maps $\Omega^{1}$ and $\Omega^{2}$.

\section{Conclusions and future perspectives}

It has been proposed the algorithm for automated conversion of geospatial objects to classifiers according to the updated standards as the result of the research. The proposed approach allows converting any differentiated GDB sets into the space of a single digital description of all instances of geospatial objects. This study meets criteria of the Infrastructure for Spatial Information in the European Community (INSPIRE) of 2007 [7,8].

The results of the development and the resulting program code can be used to solve a number of the following automation tasks:

1. Performing the conversion between the classifiers in the open working map in a layer, the ability to make the transition without opening the map but only specifying the pathname to it or a whole work card archives.

2. Intuitive display of all simple and complex signatures to the selected objects of a given layer.

3. Autocomplete and obtain new information from the spatial model: the ability to fill the top and bottom of the slope, the border according to pickets on the contour. Auto-creation, auto-linking and auto-orientation of a new point object.

4. Creating and improving the implementation of domains and subtypes in fields / attributes / semantics of a spatial object.

Properly organized structure of the GDB at the lower level of information interaction will give a significant positive result in the implementation of the concept of Zoning system, provided that its 
subsystems are ranked and automation of the processes for the retrieval of missing data at the stage of design decisions $[2,18]$.

In the future it should be implemented the validity check of the results in the data arrays conversion between the classifiers. As the result of the data transfer it may make it difficult to generate new information; not meet the information describing rules; not meet the standards of classification; be absent for some reason. Such questions are discussed in works $[3,19,26]$.

[1] Standards approved by Ukrgeodezkartographiia (2019), (in Ukrainian). http://gki.com.ua/ua/ tehnichni-komitet-103.

[2] Borovyi V. O., Kostenko O. B., Zarytskyi O. V. Ranking of information systems of branches with economic activity. Emerging Technologies. 2 (4), 5-14 (2017), (in Ukrainian).

[3] Borovyi V. O., Zarytskyi O. V., Domaratska-Parhomchuk O. S. Application of Zoning in determining the area of land under the adjoining areas. Land Management Bulletin. 10, 22-27 (2016), (in Ukrainian).

[4] Department of Urban Development and Architecture of the Kharkiv City Council. System of electronic topographic and geodetic plan of the city of Kharkov. Classifier of spatial objects of executive mapping (2018), (in Ukrainian).

[5] Draft Law. On the National Spatial Data Infrastructure. In: Laws of Ukraine. Dated April 13, 2020 N 554-IX (2020), (in Ukrainian). https://zakon.rada.gov.ua/laws/show/554-20.

[6] Dyshlyk O.P., Dorosh A. I., Tarnopolsky A. V., Tarnopolsky Y. A. Infrastructure of spatial data in Ukraine: Status and methodological problems of legislative regulation. Land Management, Cadastre and Land Monitoring. 18, 33-43 (2018), (in Ukrainian).

[7] European Commission. INSPIRE Generic Conceptual Model. In: INSPIRE Knowledge base. Data Specifications (2014). https://inspire.ec.europa.eu/documents/inspire-generic-conceptual-model.

[8] European Parliament, Council of the European Union. Directive 2007/2/EC of the European Parliament and of the Council of 14 March 2007 establishing an Infrastructure for Spatial Information in the European Community (INSPIRE) (2007).

[9] Fedorov D. V. Chapter 6. Classifier. In: Digitals. Use in geodesy, cartography and land management (2015), (in Russian). http://www.vinmap.net/book/ch06.html.

[10] Fedorov D. V. Appendix D. Introduction to Digitals Script. In: Digitals. Use in geodesy, cartography and land management (2015), (in Russian). http://www.vinmap.net/book/apd.html.

[11] ISO/TC 211 Geographic information/Geomatics. Geographic technology standard models and schemas (2020). https://www . isotc211.org.

[12] Kay S. E. Challenges in sharing of geospatial data by data custodians in South Africa. 28th International Cartographic Conference, July 2-7, 2017, Washington DC. The Proceedings of the International Cartographic Association. 1, 60 (2018).

[13] Karpinsky Yu. O., Lyaschenko A. A. New approaches to standardization and technical regulation in area of geographical information. Collection of Sciences Works Modern Achievements of Geodesic Science and Production. 1 (7), 283-291 (2004), (in Ukrainian).

[14] Karpinsky Yu. O., Lyaschenko A. A. Geographical information: reference model - the first fundamental national standard, harmonized with international standards of the series ISO 19100. Modern Achievements of Geodesic Science and Production. Collection of Scientific Works of the Western Geodesic Society. 1 (19), 198-203 (2010), (in Ukrainian).

[15] Karpinsky Yu. O., Lyaschenko A. A., Runets R. V. Standard model of topographic data base. Herald of Geodesy and Cartography. 2 (65), 28-36 (2010), (in Ukrainian).

[16] Karpinsky Yu. O., Lyaschenko A. A., Gorkovchuk M. V. Conceptual basis for estimation and quality assurance of geospatial data. Herald of Geodesy and Cartography. 4 (79), 33-42 (2012), (in Ukrainian).

[17] Karpinsky Yu. O., Lyaschenko A. A., et al. SOU 71.12-37-949:2014. Topographic database: Catalog of objects and attributes. Ministry of Agrarian Policy and Food of Ukraine, Kyiv (2014), (in Ukrainian).

[18] Kostenko O. B., Zarytskyi O. V. Decomposition with the Ranking of Information Systems for Infologic Design. Mathematical Models and New Technologies of Management of Economic and Technical Systems:

Mathematical Modeling and Computing, Vol.7, No. 2, pp. 228-238 (2020) 
Collective Monograph. For Collections. eds. Timofeev V. O., Chumachenko I. V. Kharkiv: FOP Mezina V. V. 247-260 (2017), (in Ukrainian).

[19] Kostenko O. B., Bulayenko M. V., Zarytskyi O. V. Analysis of mathematical methods of decomposition in systems for reproduction with lost data. Mathematical Models and New Technologies of Management of Economic and Technical Systems: Collective Monograph. For Collections. eds. Timofeev V. O., Chumachenko I. V. Kharkiv: FOP Mezina V. V. 261-267 (2017), (in Ukrainian).

[20] Order of Ministry of Regional Development of Ukraine. Approval of the List of Classes of Objects of the Urban Cadastre. Dated August 14, 2015 N 193 (2015), (in Ukrainian). https://zakon.rada.gov.ua/ laws/show/z1293-15.

[21] Ostensen O. M., Smits P. C. ISO / TC211: Standardization of Geographic Information and Geo-Informatics. IEEE International Geoscience and Remote Sensing Symposium. 1, 261-263 (2002).

[22] Sanderson M., RamageS., Van Linden L. SDI Communities: Data quality and knowledge sharing. Spatial Data Infrastructure Convergence: Building SDI Bridges to address Global Changes, June 15-19, 2009: Proceedings, Rotterdam. GSDI. 11, 1-27 (2009).

[23] Sossa R. I., Golubinka Y. I. Contemporary challenges to topographical surveying and cartographic support of security and defense sector of the state. Bulletin of Taras Shevchenko National University. MilitarySpecial Science. 1 (36), 20-23 (2017), (in Ukrainian).

[24] Research Institute of Geodesy and Cartography. National Infrastructure of Spatial Data of Ukraine. (2013), (in Ukrainian).

http://gki.com.ua/ua/nacionalna-infrastruktura-geoprostorovih-danih-ukraiini .

[25] Zaiets I. M., Karpinsky Yu. O., Lyaschenko A. A. Ukrainian state georgaphy on the way from infrastructure of cartographic production to infrastructure of geospatial data. Herald of Geodesy and Cartography. $\mathbf{5}$ (74), 4-11 (2011), (in Ukrainian).

[26] Zarytskyi O. V., Kostenko O. B. Uncertainty of geospatial data in a dynamic geoinformation system. 3rd International Conference Winter InfoCom Advanced Solutions 2016, Kyiv, December 1-2, 2016, (in Ukrainian).

\title{
Автоматизація конвертування геопросторових об'єктів до класифікаторів за європейськими стандартами
}

\author{
Зарицький О. В., Костенко О. Б., Булаєнко М. В. \\ Харківсъкий національний університет місъкого господарства імені О. М. Бекетова, \\ кафедра комп'ютерних наук та інформаційних технологій, факультет менеджменту, \\ вул. Маршала Бажанова, 17, 61002, Харків, Україна
}

\begin{abstract}
Досліджено концепцію формування національної інфраструктури геопросторових даних (НІГД) в Україні, проведено аналіз комплексу галузевих стандартів НІГД та класів об'єктів містобудівного кадастру. Визначено комплекс проблем, що впливають на розвиток геоінформаційних ресурсів країни. Враховуючи сучасний стан національної інфраструктури геопросторових даних та актуальність проблем використання архівних баз геопросторових даних (БГД), показано необхідність розроблення алгоритмів для створення уніфікованої основи геоінформаційних систем. Запропоновано автоматизований процес конвертації диференційованих БГД до оновлених правил цифрового опису всіх екземплярів геопросторових об'єктів. Робочі набори цифорових карт розглядаються як тривимірні масиви даних. Такий підхід уможливлюе краще орієнтуватися в алгоритмічних процесах з урахуванням великої кількості правил перетворення екземплярів між двома структурами класифікації.
\end{abstract}

Ключові слова: інфраструктура геопросторових даних, класи об'єктів, містобудівний кадастр, БГД, класибікатор, конвертування даних. 